\title{
Ooid fabric in the Jurassic of the Indus Basin, Pakistan: control on the original mineralogy
}

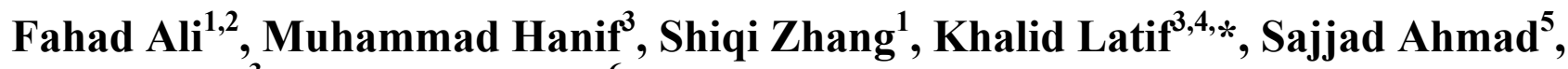 \\ Irfan U. $\mathrm{Jan}^{3}$ and Hawas Khan ${ }^{6}$ \\ ${ }^{1}$ School of Geosciences, China University of Petroleum East China, Qingdao \\ ${ }^{2}$ Department of Geology, Bacha Khan University, Charsadda, Pakistan \\ ${ }^{3}$ NCE in Geology, University of Peshawar, Peshawar, Khyber Pakhtunkhwa, Pakistan \\ ${ }^{4}$ School of Earth Sciences and Resources, China University of Geosciences, Beijing, China \\ ${ }^{5}$ Department of Geology, University of Peshawar, Peshawar, Khyber Pakhtunkhwa, Pakistan \\ ${ }^{6}$ Department of Earth Sciences, Karakoram International University, Gilgit Baltistan, Pakistan
}

\begin{abstract}
The present study provides a petrographical and geochemical analysis of the coated carbonate grains from the early-middle Jurassic strata of the Indus Basin, Pakistan. The emphasis is on the depositional fabric, original carbonate mineralogy and seawater chemistry of the recovered ooids. These coated grains are believed to have formed in a high-energy depositional setting in grain shoal to peritidal settings on a platform interior. The original mineralogy is preserved, with an overprinted mineralogy observed in a few samples. Three different microfabric types are reported, including (1) finely laminated tangential concentric ooids showing original mineralogy, (2) brickwork and moldic ooids delineating the intermediate stage and (3) micritized and leached ooids representing the overprinted mineralogy. Changes in $\mathrm{Sr}, \mathrm{Mn}, \mathrm{Fe}$ and Mg contents might have occurred during the formation of ooids, which asserts that the ooids are mono- to bi-mineralic in chemical composition. Alongside ooids, oncoids had also widely developed around the skeletal and non-skeletal allochems, which served as their nuclei.
\end{abstract}

Keywords: Jurassic strata, oncoids, ooids, original mineralogy, microfabric types.

SORBY ${ }^{1}$ pioneered the discussion on the origin and composition of ooids, laying the foundation for interpreting the complex mechanism of formation of ooids for other researchers. However, due to their debatable original mineralogy and the geological conditions prevailing during their formation, no consensus could be arrived at. The origin of ooids is proposed by some researchers to be inorganic in nature; however, uncertainties about its original depositional mineralogy still exist. This is because the modern ooids are comprised of aragonite, whereas their ancient counterparts are calcitic in nature. This difference in ooidal composition indicates a shift in the geochemical

*For correspondence. (e-mail: khalidlatif@uop.edu.pk) conditions of seawater favouring formation of the ooids as calcite or aragonite ${ }^{2-11}$, and this shift in ooids mineralogy can be recorded throughout the Phanerozoic $^{7,12}$. The change is non-skeletal carbonate allochems may be related to the rhythmic change in the seawater chemistry, which is mainly controlled by fluctuation in accretion rates of mid-oceanic ridges and hydrothermal brine solutions ${ }^{5,10,12}$. The amount of carbon dioxide present in brine solution plays a key role in providing the prerequisite for the deposition of aragonite and calcite. A higher amount of $\mathrm{CO}_{2}$ minimizes the seawater carbonate saturation, favouring the formation of calcite over aragonite. On the other hand, the lower level of oceanic and atmospheric $\mathrm{CO}_{2}$ maximizes the seawater carbonate saturation for both calcite and aragonite. Nevertheless, the kinetic factors controlling marine environments support the formation of aragonite rather than calcite ${ }^{7,9,10}$. Besides calcite and aragonite precipitation, change in the ancient carbonate mineralogy is mostly attributed to diagenetic reactions, which can be interpreted through the petrographical and geochemical studies of ooids. The modern oolitic layers are comprised of tangentially oriented aragonite crystals, while the ancient ooids preferably show radially arrayed calcite crystals ${ }^{13,14}$. Furthermore, the cortices in the ancient ooids are composed of interlocking equant calcite crystals; nevertheless, such an occurrence is less commonly recorded. Previous studies (e.g. Cantrell $^{11}$ and references therein) suggest that the difference in the sorting, shape, roundness and sphericity of the ooidal cortices defines the radial layer arrangement in ancient ooids to be a syndepositional fabric. Such layering is not formed from secondary overprinting during diagenesis. A noteworthy contribution is to prove that the calcitized aragonite comprises of interlocked crystals of equant, anhedral $\operatorname{spar}^{12}$. This evidence is reinforced by observing that in skeletal allochems, the original primary aragonites have been substituted by equant crystals of calcite spar $^{2}$.

According to Sandberg ${ }^{15}$, the standards used for identification of original non-skeletal aragonite allochems are: (1) 
aragonite are rarely preserved in ancient carbonates, which helps in identifying the primary chemical composition; (2) coarse mosaic calcite crystals developed in the calcitized grains, cross-cutting the original morphology, and containing oriented aragonite inclusion mostly; (3) the unaltered mosaic calcite crystals possess high strontium content if they do not preserve aragonite relic; (4) the diagenetically altered calcitized mosaic crystals lack aragonite relic and high strontium content; (5) presence of cement-filled moulds or moldic pores, and (6) preservation of the fine ooidal fabric in the apparently calcitized non-skeletal allochems.

In this study, we analyse the oolitic limestone deposited in the Jurassic strata of the Indus Basin, Pakistan, to provide significant evidences toward understanding the original composition of ooids. The variation in morphology and size of the deposited ooids and associated oncoids was recorded across a range of geographical locations from the Indus basin (Figure 1). The main focus of this study is to describe the petrographical and geochemical characteristics of the Jurassic ooids and oncoids from the Indus Basin. The mechanism depositing the original composition has been discussed. The present study provides significant clues regarding original mineralogy and palaeodepositional environment of Jurassic ooids.

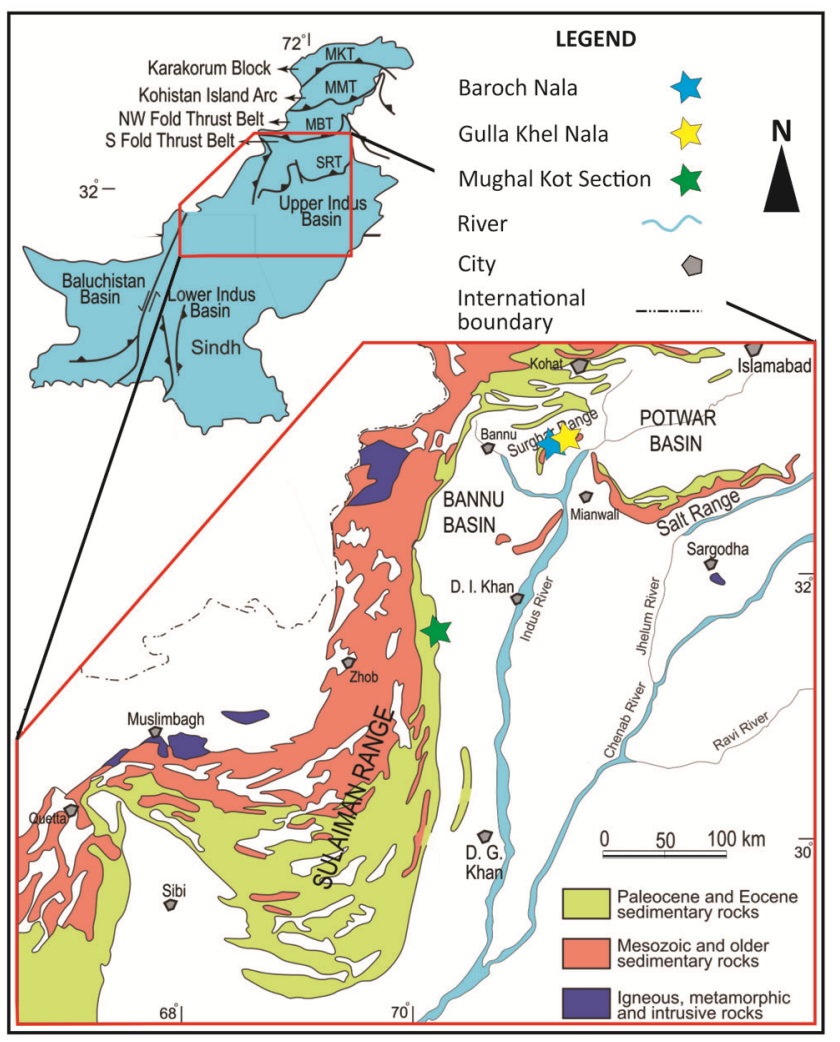

Figure 1. Map of Pakistan, showing geographical location of the study area. The inset shows location of the studied sections in the Indus Basin, Pakistan.

\section{Geological setting}

The Indus Basin of Pakistan consists of the late Palaeozoic to Recent geological strata deposited along the northwestern edge of the Indian subcontinent (Figure $1)^{16}$. These sedimentary successions cover two-thirds of Pakistan, with their axis generally coinciding with the course of the Indus River ${ }^{17}$. The Mesozoic strata in the Indus Basin are represented by clastic and carbonate rocks, including sandstone, organic black shale, coal, limestone, marls, dolomite, chert and laterite ${ }^{18}$. The stratigraphy of the Jurassic in this basin is represented by Datta, Shinawari and Samana Suk Formations in the upper Indus Basin, while in the Lower Indus Basin by the Shirinab, Chilton and Mazar Drick Formations (Figures 2 and 3$)^{18-21}$. Several studies on the sedimentology and stratigraphy of the Indus Basin are available in the literature $^{16,21-37}$.

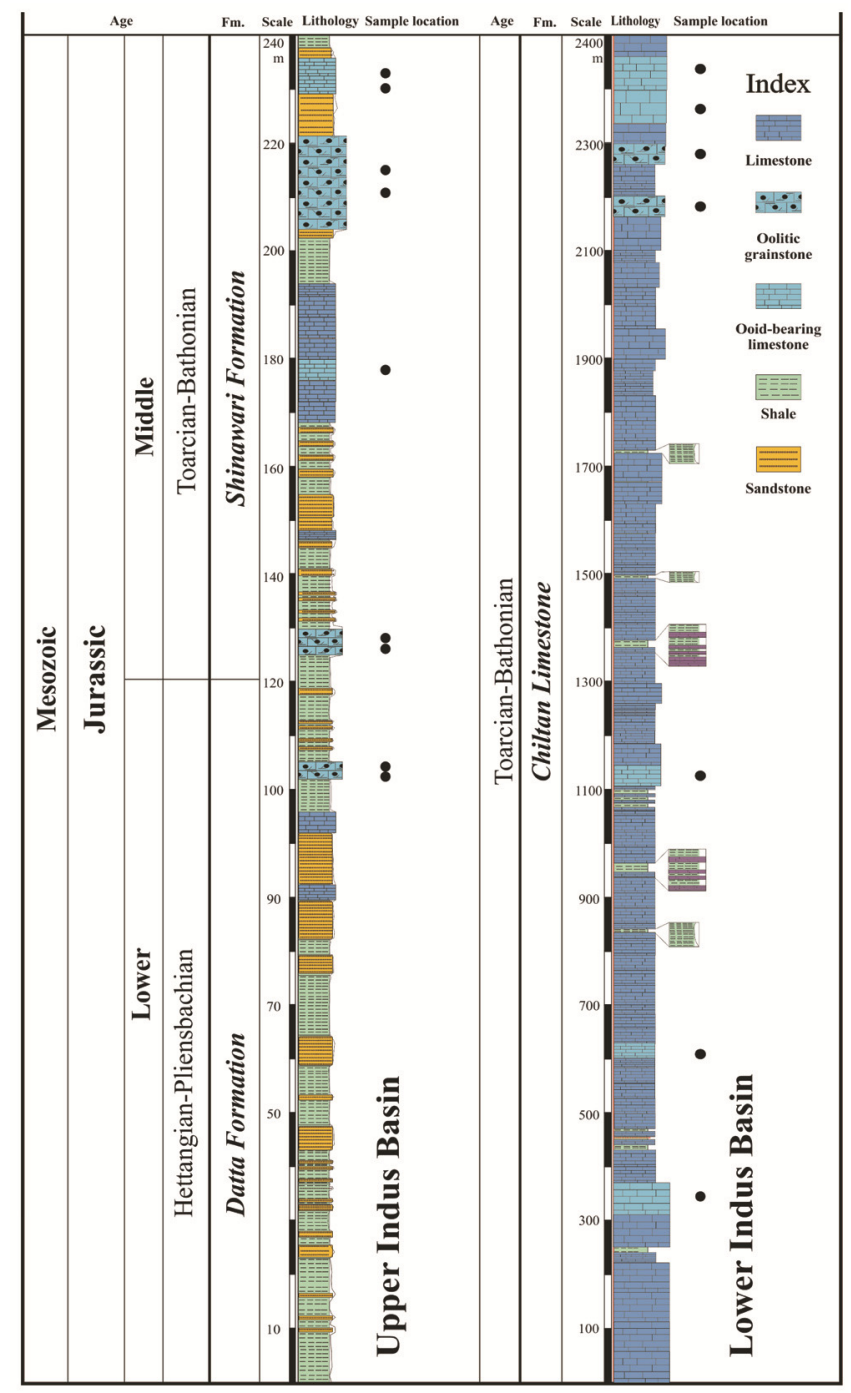

Figure 2. Generalized stratigraphic log of the Jurassic successions in the studied sections.

CURRENT SCIENCE, VOL. 119, NO. 5, 10 SEPTEMBER 2020 
RESEARCH ARTICLES

Table 1. Elemental composition of the selected samples analyzed through energy dispersive system (EDS) point analysis

\begin{tabular}{|c|c|c|c|c|c|c|c|c|c|c|c|c|c|c|c|}
\hline \multirow{2}{*}{\multicolumn{2}{|c|}{$\begin{array}{l}\text { Section } \\
\text { and } \\
\text { sample no. }\end{array}$}} & \multirow[b]{2}{*}{$\mathrm{O}$} & \multirow[b]{2}{*}{$\mathrm{C}$} & \multirow[b]{2}{*}{$\mathrm{Na}$} & \multicolumn{10}{|c|}{ Elemental composition (wt\%) } & \multirow{2}{*}{$\begin{array}{c}\text { Reference to } \\
\text { figure }\end{array}$} \\
\hline & & & & & $\mathrm{Mg}$ & $\mathrm{Al}$ & $\mathrm{Si}$ & $\mathrm{Cl}$ & $\mathrm{Ca}$ & $\mathrm{K}$ & $\mathrm{Mn}$ & $\mathrm{Sr}$ & $\mathrm{Fe}$ & $\mathrm{S}$ & \\
\hline \multirow{20}{*}{ 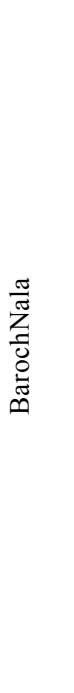 } & \multirow{20}{*}{ 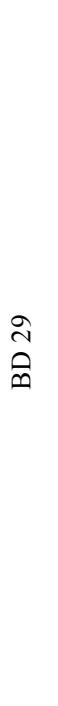 } & 42.34 & 21.11 & 0.21 & 0.36 & 0.6 & 0.67 & 0.24 & 26.16 & 0 & 0 & 0 & 6.96 & 0 & Figure $10 a$ \\
\hline & & 49.42 & 13.12 & 0 & 0.3 & 0.21 & 0.37 & 0.18 & 33.59 & 0 & 0 & 0 & 1.02 & 0 & \\
\hline & & 50.92 & 21.57 & 0.33 & 0.29 & 0.25 & 0.43 & 0.21 & 25.16 & 0 & 0 & 0 & 0.84 & 0 & \\
\hline & & 47.65 & 21.68 & 0.44 & 0.37 & 0.4 & 0.98 & 0.18 & 26 & 0 & 0 & 0 & 1.23 & 0 & \\
\hline & & 44.87 & 20.83 & 0 & 0.19 & 0.54 & 0.89 & 0.29 & 29.44 & 0 & 0 & 0 & 1.36 & 0 & \\
\hline & & 59.86 & 0.36 & 0.56 & 0 & 0 & 0 & 21.84 & 0.01 & 0 & 0 & 0 & 1.71 & 0 & Figure $10 b$ \\
\hline & & 53.9 & 0.39 & 0.35 & 0 & 0.08 & 0.18 & 32.31 & 0 & 0 & 0 & 0 & 0.82 & 0 & \\
\hline & & 44.76 & 0.31 & 0.5 & 0.19 & 0.26 & 0.23 & 40.12 & 0 & 0 & 0 & 0 & 3.41 & 0 & \\
\hline & & 39.87 & 0.33 & 0.61 & 0.23 & 0.27 & 0.34 & 37.24 & 0 & 0 & 0 & 0 & 11.93 & 0 & \\
\hline & & 56.44 & 0 & 0.34 & 0.17 & 0.19 & 0.09 & 27.99 & 0 & 0 & 0 & 0 & 0.68 & 0 & \\
\hline & & 54.92 & 0 & 0.51 & 0.43 & 0.59 & 0 & 26.91 & 0 & 0 & 0 & 0 & 0.87 & 0 & \\
\hline & & 55.54 & 17.28 & 0 & 0.36 & 0.22 & 0.18 & 0 & 26.43 & 0 & 0 & 0 & 0 & 0 & Figure $10 c$ \\
\hline & & 46.76 & 17.42 & 0.33 & 0.37 & 0.33 & 0.35 & 0 & 33.21 & 0 & 0 & 0 & 1.23 & 0 & \\
\hline & & 38.95 & 20.75 & 0.92 & 0.3 & 0.35 & 0.55 & 3.14 & 30.11 & 2.41 & 0 & 0 & 1.4 & 0 & \\
\hline & & 42.47 & 32.23 & 0.66 & 0.29 & 0.41 & 1.15 & 0.22 & 20.77 & 0 & 0 & 0 & 0.86 & 0 & \\
\hline & & 45.99 & 20.53 & 0.7 & 0.41 & 0.56 & 0.78 & 0.33 & 28.78 & 0 & 0.1 & 0 & 0.85 & 0 & Figure $10 d$ \\
\hline & & 47.98 & 20.52 & 0.48 & 0.47 & 0.33 & 0.38 & 0.16 & 28.77 & 0 & 0 & 0 & 0.92 & 0 & \\
\hline & & 50.81 & 22.34 & 0.83 & 0.28 & 0.3 & 0.14 & 0.18 & 24.21 & 0 & 0 & 0 & 0.91 & 0 & \\
\hline & & 52.27 & 21.45 & 0.36 & 0.36 & 0.3 & 0.43 & 0.67 & 23.52 & 0 & 0 & 0 & 0.62 & 0 & \\
\hline & & 45.93 & 24.74 & 1.07 & 0.55 & 0.32 & 0.38 & 1.47 & 23.47 & 1.18 & 0 & 0 & 0.89 & 0 & \\
\hline \multirow{5}{*}{$\begin{array}{l}\bar{\Xi} \\
\frac{\pi}{\Xi} \\
\frac{\pi}{\Xi} \\
Z\end{array}$} & \multirow{5}{*}{$\vec{\infty}$} & 44.43 & 33.86 & 0.51 & 0.94 & 0.43 & 0.8 & 0 & 19.03 & 0 & 0 & 0 & 0 & 0 & - \\
\hline & & 50.89 & 19.01 & 0 & 0.5 & 0 & 0.25 & 0 & 29.36 & 0 & 0 & 0 & 0 & 0 & \\
\hline & & 47.6 & 28.64 & 0 & 1.21 & 0 & 22.55 & 0 & 0 & 0 & 0 & 0 & 0 & 0 & \\
\hline & & 39.45 & 29.11 & 0 & 0.53 & 0.68 & 1.25 & 0 & 28.06 & 0 & 0 & 0 & 0.93 & 0 & - \\
\hline & & 31.33 & 50.46 & 1.06 & 0 & 0 & 1.29 & 0.98 & 14.88 & 0 & 0 & 0 & 0 & 0 & \\
\hline \multirow{15}{*}{$\begin{array}{l}\stackrel{0}{0} \\
\underline{1} \\
\frac{\pi}{00} \\
\stackrel{0}{\Xi}\end{array}$} & \multirow{7}{*}{$\begin{array}{l}m^{+} \\
\dot{M}\end{array}$} & 7.19 & 0 & 0 & 0 & 0 & 1.23 & 1.67 & 89.03 & 0 & 0 & 0 & 0 & 0.87 & Figure $10 e$ \\
\hline & & 49.32 & 9.25 & 10.56 & 1.9 & 0.32 & 25.24 & 0 & 3.41 & 0 & 0 & 0 & 0 & 0 & \\
\hline & & 47.29 & 25.73 & 0.81 & 0.29 & 0 & 0.8 & 0.18 & 24.9 & 0 & 0 & 0 & 0 & 0 & \\
\hline & & 44.32 & 24.71 & 0.37 & 0.33 & 0.24 & 0.28 & 0.91 & 28.84 & 0 & 0 & 0 & 0 & 0 & \\
\hline & & 40.62 & 29.24 & 0 & 0 & 0 & 0 & 0 & 30.09 & 0 & 0.05 & 0.01 & 0 & 0 & - \\
\hline & & 38.27 & 32.16 & 0.61 & 0 & 0 & 1.68 & 0.43 & 25.58 & 0 & 0 & 0 & 0 & 0 & \\
\hline & & 41.5 & 28.42 & 0 & 0 & 0 & 0 & 0 & 30.07 & 0 & 0.01 & 0.01 & 0 & 0 & \\
\hline & \multirow{8}{*}{$\begin{array}{l}n \\
\vdots \\
\Sigma\end{array}$} & 35.51 & 36.14 & 0.99 & 0.5 & 0.65 & 1.23 & 0.49 & 22.83 & & 0.001 & 0.1 & 0.001 & 0 & - \\
\hline & & 34.78 & 25.24 & 0.3 & 0.4 & 0.001 & 0.14 & 0.001 & 37.58 & 0 & 0.003 & 0.5 & 0 & 0 & \\
\hline & & 44.79 & 26.91 & 0.01 & 9.22 & 0.001 & 0.24 & 0.002 & 17.33 & 0 & 0.02 & 0.07 & 0.07 & 0 & \multirow{6}{*}{ Figure $10 f$} \\
\hline & & 50.65 & 20.77 & 0 & 10.29 & 0 & 0 & 0 & 15.43 & 0 & 0.06 & 0.19 & 1.18 & 0 & \\
\hline & & 52.27 & 19.85 & 0 & 10.69 & 0 & 0 & 0 & 14.89 & 0 & 0.1 & 0.05 & 1.05 & 0 & \\
\hline & & 24.6 & 7.3 & 0 & 3.96 & 0 & 0 & 1 & 61.51 & 0 & 0.03 & 0.02 & 1.18 & 0 & \\
\hline & & 35.94 & 34.34 & 0 & & 0 & 0.6 & 0 & 28.72 & 0 & 0.13 & 0.13 & 0.14 & 0 & \\
\hline & & 23.66 & 32.39 & 0 & 5.3 & 0 & 0.33 & 0 & 35.91 & 0 & 0.18 & 0.19 & 0.15 & 0 & \\
\hline
\end{tabular}

\section{Materials and methods}

Field data were collected from oolitic grainstone and ooid-bearing limestone of early-middle Jurassic outcrops in Baroch Nala (30 samples) and Gulla Khel Nala (20 samples) sections in the Surghar Rang, Upper Indus Basin, and Mughal Kot Section (25 samples) in the Sulaiman Range, Lower Indus Basin (Figures 1-3). These strata were sampled for petrographical and geochemical analyses. For petrographical analysis, thin sections were prepared following the standard procedure ${ }^{38}$. The qualitative and semi-quantitative data were obtained from the thin sections. The samples preserving better original fabric and with lesser diagenetic alteration were selected for scanning electron microscopy (SEM) and geochemi- cal analysis. Ultrastructural features of ooids were obtained through SEM loaded with energy dispersive $\mathrm{X}$-rays sepctroscopic system (EDS), secondary electron detector (SED) and backscattered electron detector (BED). Elemental composition along selected points and areas were determined through EDS. The bulk geochemical analysis of ooids was carried out using X-ray fluorescence (XRF). Tables 1-3 show results of the quantitative geochemical results obtained from EDS and XRF.

\section{Results}

\section{Petrography}

The microscopic observation of ooids helps in measuring their size, which was recorded between 256 and $2000 \mu \mathrm{m}$. 


\section{RESEARCH ARTICLES}

Table 2. Elemental composition of the selected samples analysed through EDS area analysis

\begin{tabular}{|c|c|c|c|c|c|c|c|c|c|c|c|c|c|c|}
\hline \multirow{2}{*}{\multicolumn{2}{|c|}{ Section and sample no. }} & \multicolumn{12}{|c|}{ Elemental composition (wt\%) } & \multirow{2}{*}{$\begin{array}{l}\text { Reference } \\
\text { to figure }\end{array}$} \\
\hline & & $\mathrm{C}$ & 0 & $\mathrm{Na}$ & $\mathrm{Mg}$ & Al & $\mathrm{Si}$ & $\mathrm{Cl}$ & $\mathrm{Ca}$ & $\mathrm{Fe}$ & $\mathrm{Sr}$ & $\mathrm{Mn}$ & $\mathrm{K}$ & \\
\hline \multirow{2}{*}{ BarochNala } & BD 29 & 18.39 & 49.95 & 0.61 & 0.31 & 0.25 & 6.93 & 0.4 & 21.73 & 1.08 & 0.36 & 0.01 & 0 & \multirow[b]{2}{*}{ Figure $10 g$} \\
\hline & & 18.47 & 52.19 & 0 & 0 & 0 & 0.88 & 0 & 26.98 & 1.28 & 0.14 & 0.07 & 0 & \\
\hline \multirow[t]{2}{*}{ Gulla Khel Nala } & GS 1 & 60.5 & 19.18 & 0.52 & 0 & 2.22 & 10.23 & 0.47 & 3.46 & 0 & 0 & 0.001 & 3.41 & \\
\hline & & 28.5 & 42.21 & 0.44 & 0.82 & 1.19 & 3.19 & 0.22 & 22.24 & 1.18 & 0 & 0 & 0 & - \\
\hline \multirow[t]{5}{*}{ Mughal Kot } & MC 34 & 19.46 & 48.17 & 0 & 0 & 0 & 0 & 0 & 32.25 & 0.04 & 0.001 & 0.09 & 0 & \\
\hline & & 15.07 & 51.44 & 0 & 0 & 0 & 0 & 0 & 33.49 & 0.01 & 0.01 & 0.001 & 0 & - \\
\hline & & 19.81 & 47.87 & 0 & 0 & 0 & 0 & 0 & 32.31 & 0.01 & 0.005 & 0.001 & 0 & \\
\hline & MC 37 & 25.7 & 45.34 & 0 & 2.04 & 0 & 1.29 & 0 & 26.73 & 0.17 & 0.19 & 0.02 & 0 & Figure $10 h$ \\
\hline & & 25.1 & 45.27 & 0 & 2.76 & 0 & 1.34 & 0 & 25.16 & 0.18 & 0.15 & 0.01 & 0 & \\
\hline
\end{tabular}

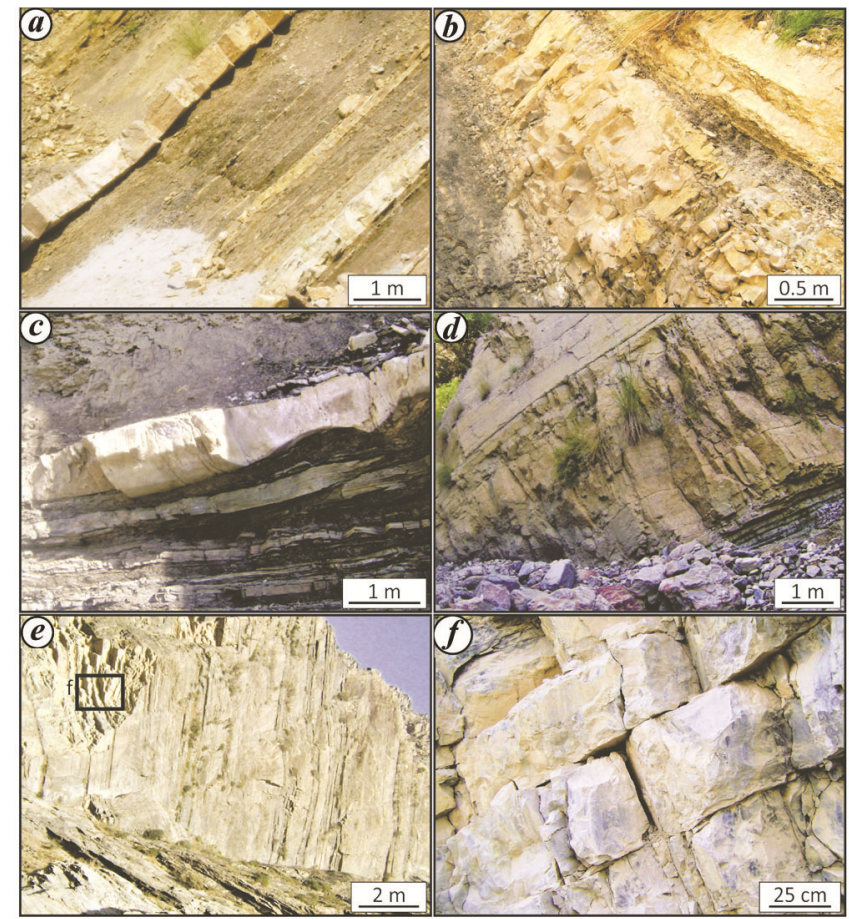

Figure 3. Outcrop view of the Jurassic strata exposed along the studied sections. (a) Ooid-bearing limestone and $(\boldsymbol{b})$ oolitic grainstone in the Datta Formation at the Baroch Nala section. (c) Thin-bedded oolitic limestone overlain by quartzose sandstone in the Datta Formation. (d) Upper contact of Shinawari Formation with the Samana Suk Formation at Gulla Khel Nala section. (e) Oolitic limestone in the Chilton Formation and $(\boldsymbol{f})$ its enlarged part at the Mughal Kot section.

They occur as perfectly rounded spherical grains or wellrounded grains with low sphericity, and display concentric-tangential, radiated-concentric, completely radiated, moldic, micritized, leached and brickwork fabrics (Figures 4-6). In general, ooids display thin fabricated laminae in circular concentric forms. They can also be seen as grapestone (Figure 5), with intraclast. The local development of the intra-cortical leaching is one of the significant features of the ooids (Figures 4-6). This leaching is fabric-selective, and is commonly restrained within single

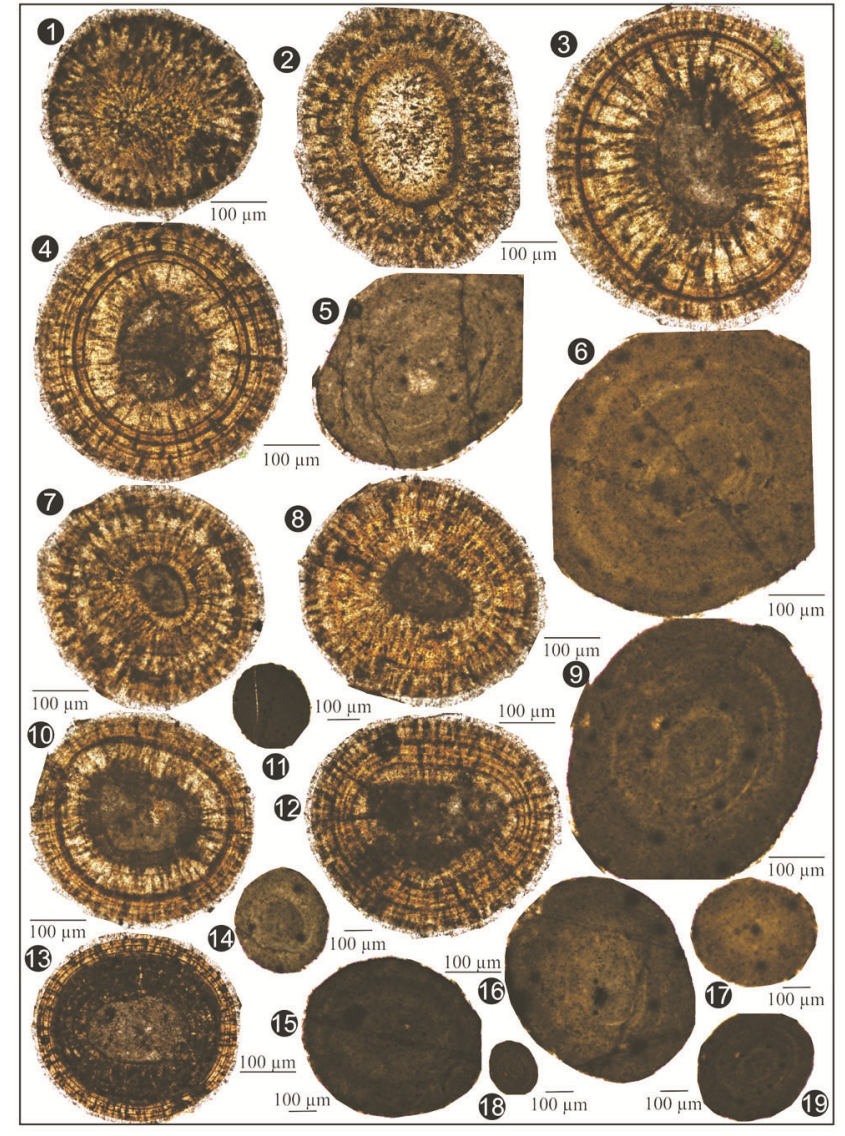

Figure 4. Diversified ooid microfabric in the Jurassic strata of the Indus Basin, Pakistan. Mosaic (1), finely laminated concentrictangential $(5,6,9,11,13-19)$, radial-concentric leached $(\mathbf{2}-\mathbf{4}, \mathbf{7 - 8}, \mathbf{1 0}$, 12), and bi-mineralic $(\mathbf{1 0}, \mathbf{1 2}, 13)$.

ooidal lamella. In each ooid, a fine, black, insoluble organic layer acts as the medium of separation between lamellae ${ }^{11}$. Typically, the leaching cross-cuts the adjacent lamella in rare cases. The micro-moldic pores generated by leaching of lamella are well-preserved only when there exists an insoluble layer between the ooid lamellae. The cementing materials present in 
RESEARCH ARTICLES

Table 3. Elemental composition of the selected samples analysed through X-ray fluorescence (XRF) analysis

\begin{tabular}{|c|c|c|c|c|c|c|c|c|c|c|c|}
\hline \multirow[b]{2}{*}{ Section } & \multirow[b]{2}{*}{ Sample no. } & \multicolumn{10}{|c|}{ Elemental composition (\%) } \\
\hline & & $\mathrm{Na}$ & $\mathrm{Al}$ & $\mathrm{Mg}$ & $\mathrm{Ca}$ & $\mathrm{Si}$ & $\mathrm{K}$ & $\mathrm{Mn}$ & $\mathrm{P}$ & $\mathrm{Fe}$ & $\mathrm{Ti}$ \\
\hline \multirow[t]{2}{*}{ Baroch Nala } & BD 26 & 0.006 & 0.299 & 0.61 & 53 & 2.17 & 0.064 & 0.025 & 0.0125 & 0.2234 & 0.0098 \\
\hline & BD 29 & 0.003 & 0.4891 & 0.5105 & 51.393 & 3.0002 & 0.075 & 0.0381 & 0.0143 & 0.2844 & 0.0147 \\
\hline \multirow[t]{2}{*}{ Gulla Khel Nala } & GS 1 & 0.0003 & 1.2017 & 3.1309 & 41.256 & 5.5906 & 0.4397 & 0.0699 & 0.0071 & 0.5629 & 0.0295 \\
\hline & GS 2 & 0.0003 & 1.0629 & 2.393 & 43.885 & 4.5355 & 0.4185 & 0.1226 & 0.0054 & 1.0901 & 0.0295 \\
\hline \multirow[t]{6}{*}{ Mughal Kot } & MC 15 & 0.0060 & 0.0237 & 0.1773 & 57.934 & 0.103 & 0.0003 & 0.0006 & 0.0017 & 0.0002 & 0.0004 \\
\hline & MC 21 & 0.006 & 0.538 & 1.0787 & 51.216 & 2.6801 & 0.0915 & 0.0006 & 0.0017 & 0.0628 & 0.0146 \\
\hline & MC 32 & 0.0325 & 0.7229 & 0.5477 & 32.868 & 13.834 & 0.1091 & 0.0006 & 0.0017 & 0.0222 & 0.0047 \\
\hline & MC 34 & 0.0303 & 0.1016 & 0.2219 & 56.942 & 0.5389 & 0.0169 & 0.0006 & 0.0017 & 0.0143 & 0.0049 \\
\hline & MC 49 & 0.003 & 0.041 & 0.3498 & 57.292 & 0.2787 & 0.0033 & 0.0063 & 0.0017 & 0.0542 & 0.0004 \\
\hline & MC 50 & 0.006 & 0.136 & 0.512 & 56.506 & 0.5228 & 0.0169 & 0.0006 & 0.0017 & 0.0057 & 0.0048 \\
\hline
\end{tabular}

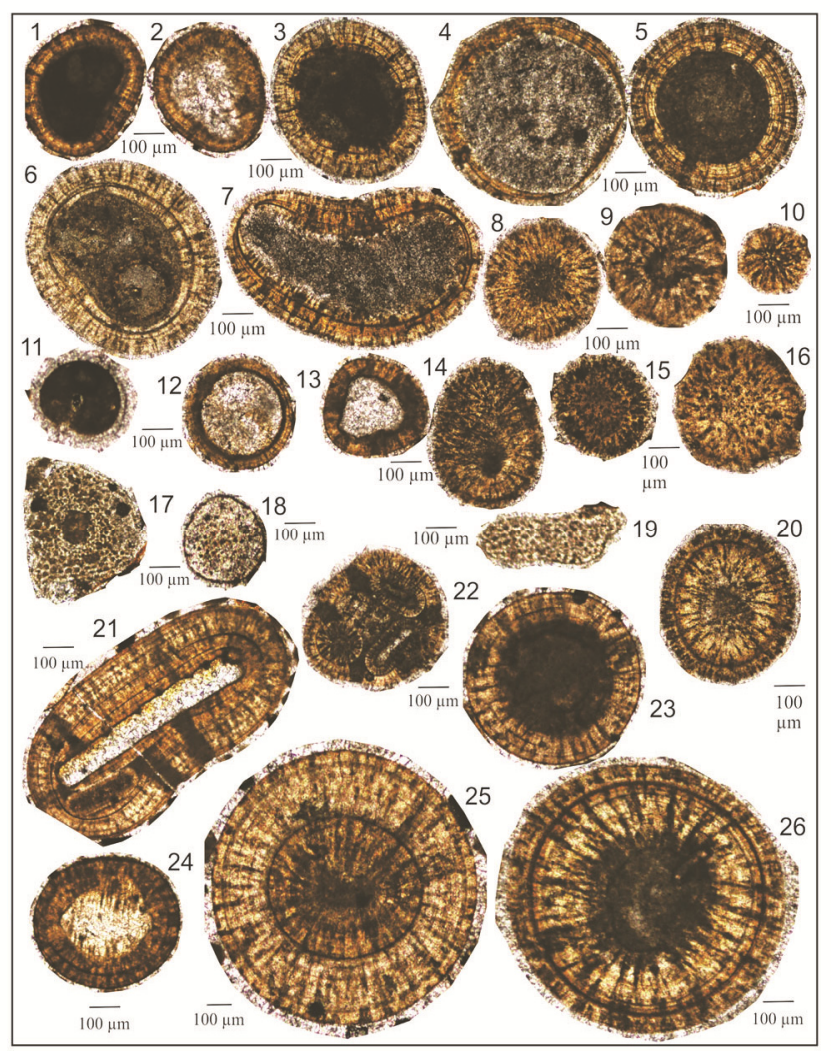

Figure 5. Diversified ooid microfabric in the Jurassic strata of the Indus Basin, Pakistan. Bi-mineralic (1-7), mosaic (8-10, 14-16, 20), moldic (11-13) brickwork replacement (17-19), grapestone (22), and finely laminated radial-concentric leached (21, 23-26).

the grainstone facies of the Jurassic strata in the Indus Basin are finely crystalline, equant mosaic and bladed type (Figure 7). These calcite cement crystals display distinct crystal boundaries and show no evidence of being partially leached. In many cases, cement has only partially blocked these intra-cortical moldic pores. Locally, the layers around a nucleus appear similar to those seen in many ancient ooids (Figures 4-6).

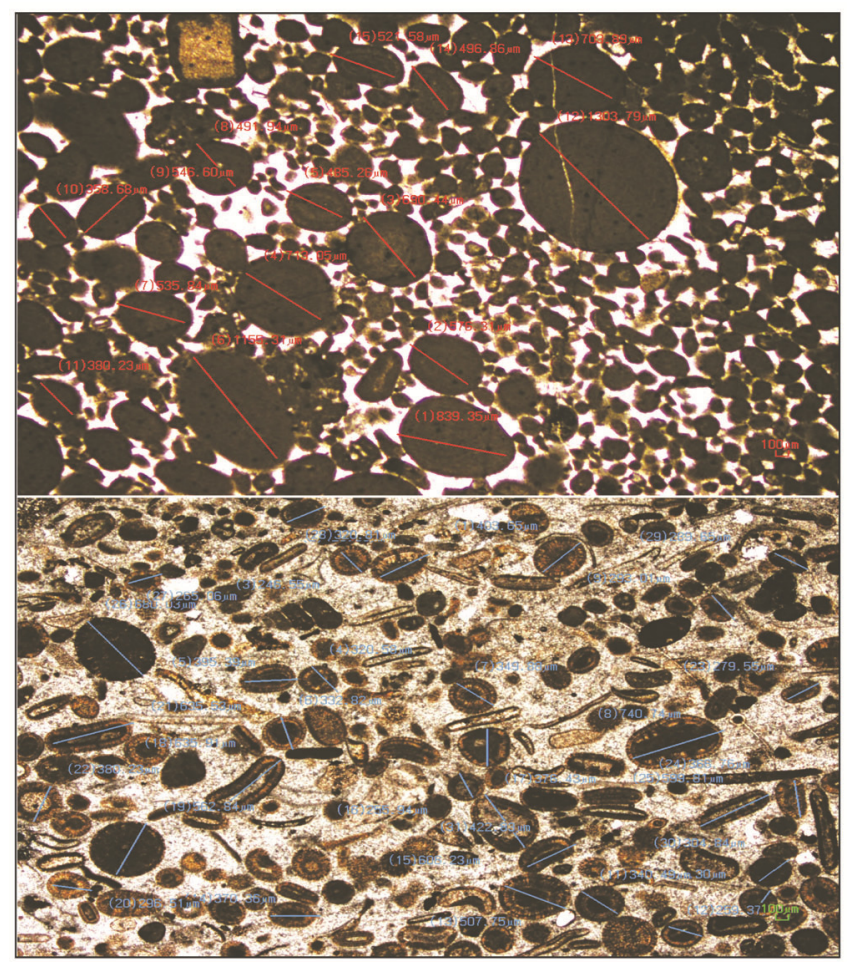

Figure 6. Morphometric analysis of ooids showing statistical measurement of individual forms.

The other dominant type of non-skeletal allochem is oncoid. The shape of the oncoids is circular, elongated or spherical, with a nucleus of skeletal allochem such as gastropods, brachiopods and echinoderms, or non-skeletal allochems such as quartz and peloids (Figure 8). The size of oncoids varies from 866 to $8234 \mu \mathrm{m}$ (Figures 8 and 9). They are present without any pronounced internal modification, displaying finely fabricated laminae with a well-developed concentric tangential structure. Some previous ooids are now converted into oncoids by becoming nuclei for the latter. The oncoids are mostly perfectly rounded with perfect spherical shape, while some forms have ellipsoidal shapes with low sphericity. The mosaic 


\section{RESEARCH ARTICLES}

cement is predominantly present between adjacent oncoids in the studied sections. Two types of mosaic cement have been identified, i.e. bladed isopachous and more equant blocky. The bladed form is relatively less observed compared to the equant blocky cement that is

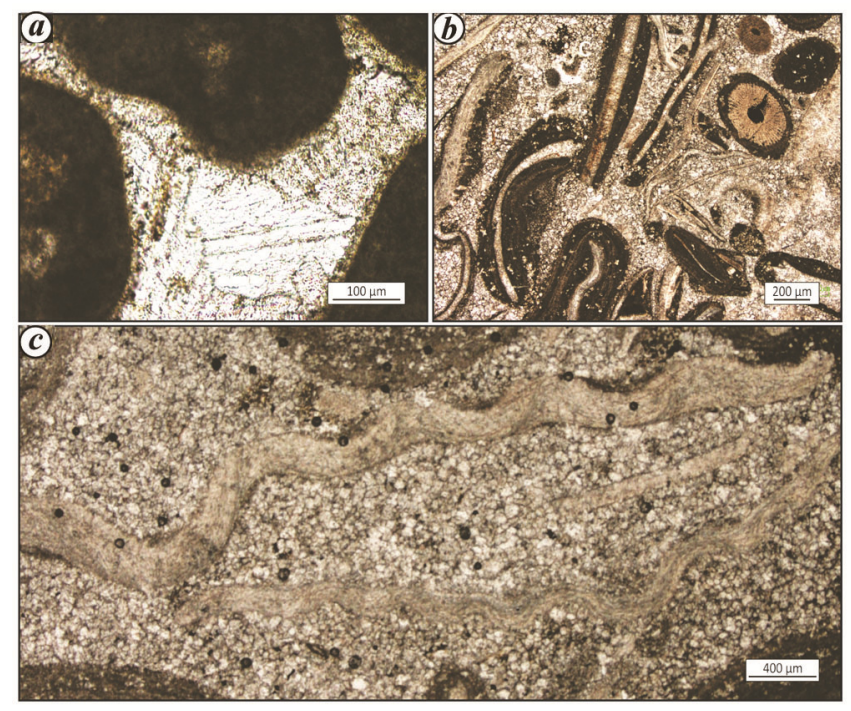

Figure 7. Variety of cement associated with ooids. $(\boldsymbol{a}, \boldsymbol{b})$ Equant and (c) bladed.

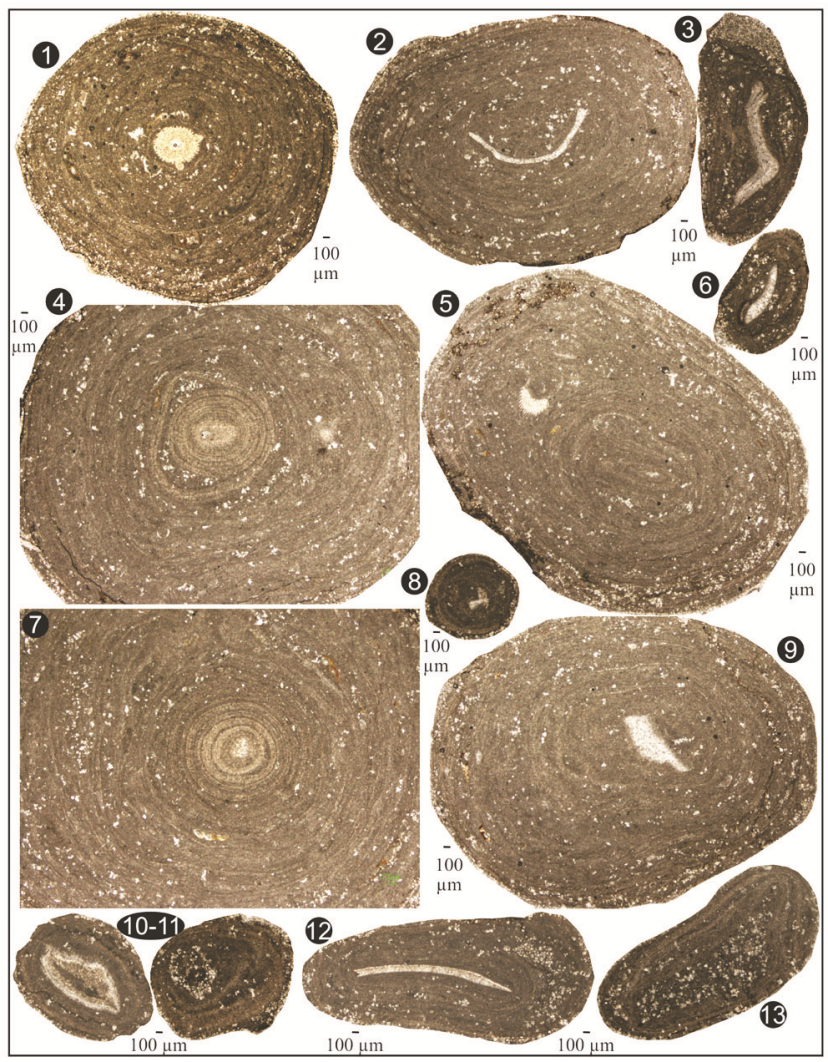

Figure 8. (1-13) Diversified ooid microfabric in the Jurassic strata of the Indus Basin, Pakistan, showing finely laminated concentrictangential oncoids. typically attached to the grain boundaries, and partially or completely blocking the primary porosity ${ }^{11}$. The bladed cement is thought to have formed in the first phase of early marine cement generation, while the equant blocky is restricted to secondary moldic pores, or in primary pores formed during the process of freshwater diagenesis ${ }^{11,39,40}$. Although leaching and micritization have occurred, the original aragonitic and intermediate brickwork texture is persevered; so the effect of freshwater diagenesis is inferred to have a minimal extent and duration.

The allochems found in association with ooids and oncoids include skeletal and non-skeletal grains, e.g. peloid, gastropod, bivalve, intraclast, grapestone, brachiopod, green algae and echinoderm. The associated aragonite allochems may be completely recrystallized, in which the calcite crystals appear to have radial orientation. The allochems originally composed of calcite (brachiopod and echinoderm) appear as well-preserved and unleached, and are readily identified (Figures 4 and 8) (see Cantrell ${ }^{11}$ ).

Interpretation: Ooids are important palaeoenvironmental indicators for ocean water energy, depth, salinity and temperature 8,39 . Physical and chemical conditions

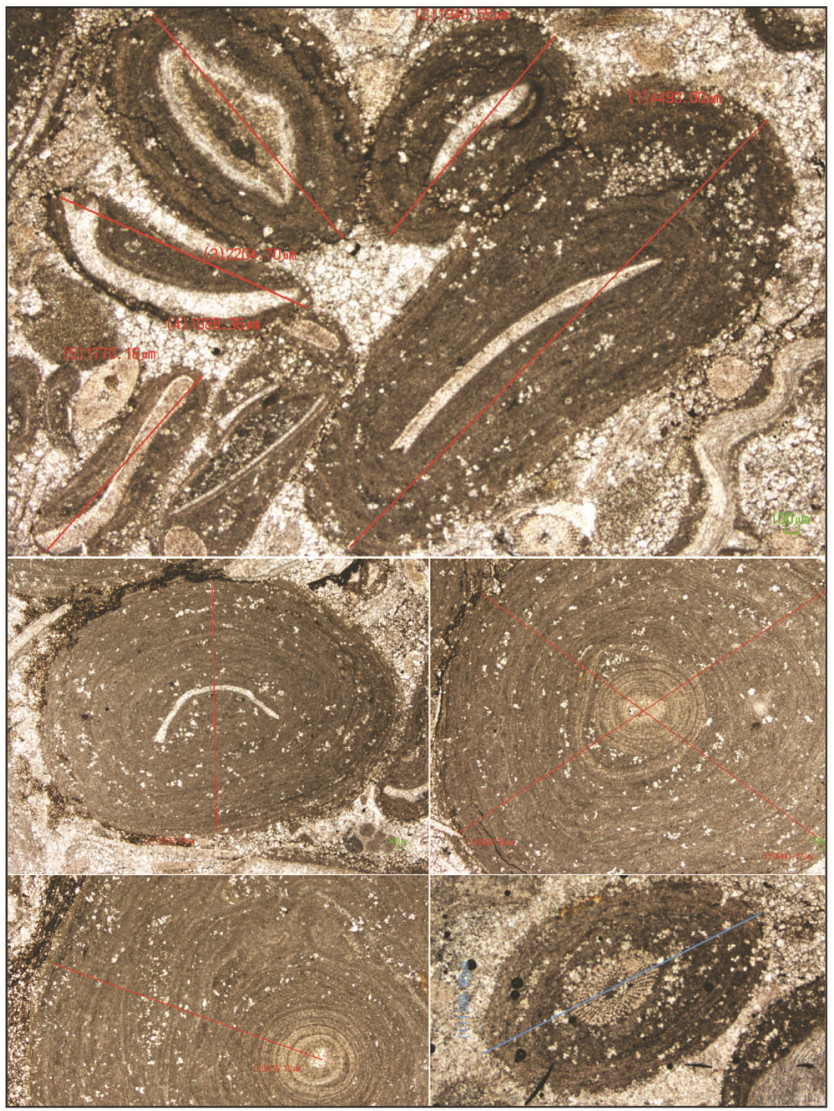

Figure 9. Morphometric analysis of oncoids showing statistical measurement of individual forms. 
prevailing during ooid deposition are recognized from their microfabric, quantity, dimension and chemistry ${ }^{41}$. A high level of super-saturation with respect to carbonate, presence of nuclei and high energy conditions are required for the formation of ooids ${ }^{39}$. According to Flügel $^{39}$, the relationship between water depth and ooids is such that depth of water should be least and the required energy must be high for a longer period of time. Current ooids are completely spherical with radial or concentric laminae, or having large nuclei resulting in superficial forms, or micritized. The concentric ooids are believed to have formed in shallow-marine, high-energy geological zones, i.e. agitated marine environment such as oolitic shoals, tidal bars and beaches ${ }^{39,42}$. The radial ooids, however, usually form in moderate to low-energy zones having high or variable salinity, thus showing lagoonal and sea-marginal or lacustrine environments ${ }^{39}$.

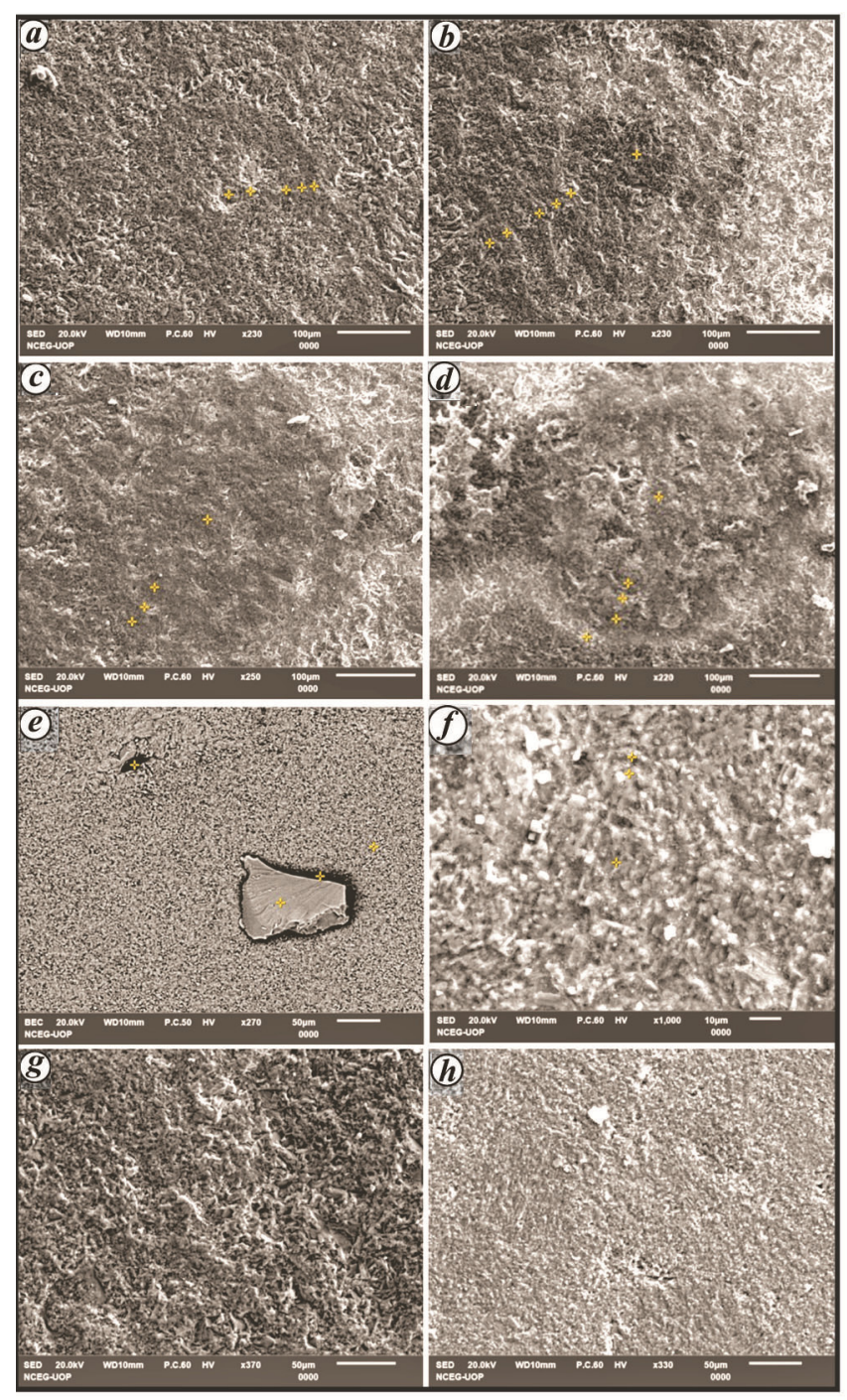

Figure 10. Ultrastructural images of ooids and associated sediments selected for EDS point $(\boldsymbol{a}-\boldsymbol{f})$ and area $(\boldsymbol{g}, \boldsymbol{h})$ analysis. Analytical data in statistical format are displayed in Tables 1 and 2.
The salinity tolerance of echinoderm ranges to a few parts per million (ppm), so it is common and abundant in normal marine geological setting, i.e. open shelf or platform deposits ${ }^{41}$. Whereas the superficial ooids form when larger nuclei are transported back and forth for a short time interval ${ }^{2}$.

The Jurassic oolitic grainstone facies in the Indus Basin are deposited in a high-energy setting such as sand beach shoal (an open platform interior). The interpretation is based on the negligible amount of mud present with diagnostic fauna, textural features and overall regional geologic and stratigraphic setting ${ }^{39,43,44}$. Besides well-preserved features, the diagenesis also plays a role in the obliteration of original features of the Jurassic sediments. For example, the isopachous bladed cement and micritization (important cementation episode in this study) show an early phase of marine diagenesis, while the less common allochem leaching and rare equant calcite cement portray later phase of freshwater diagenesis. In most cases, leaching exhibits a mineralogy change, such as the allochems originally comprised of aragonite (e.g. gastropods, bivalves and dasycladacean algae) are leached, while the allochems originally composed of calcite are not noticeably affected by diagenesis.

Geochemistry: The geochemical results are based on EDS (point and area) analysis (Tables 1 and 2) as well as XRF analysis (Table 3). The EDS (point and area) analysis was conducted on individual ooids observed in thin section. The qualitative studies show strontium ( $\mathrm{Sr}$ ), manganese $(\mathrm{Mn})$, chlorine $(\mathrm{Cl})$, aluminium $(\mathrm{Al})$, calcium $(\mathrm{Ca})$, phosphorus $(\mathrm{P})$, magnesium $(\mathrm{Mg})$, Iron $(\mathrm{Fe})$, Titanium $(\mathrm{Ti})$, Silicon (Si), Gold (Au), Manganese (Mn), Potassium (K) and Sodium $(\mathrm{Na})$, while the semi-quantitative studies comprise of all the above-mentioned elements, except $\mathrm{Ca}$, $\mathrm{C}$ and O. Data obtained from the EDS (point and area) analysis indicate that $\mathrm{Mn}, \mathrm{Sr}$ and $\mathrm{Fe}$ generally show constant values across the centre and cortical lamellae (Figures 10 and 11; Tables 1 and 2). However, some elemental data show variation in statistical values that may reflect the change in ooid mineralogy ${ }^{11}$. In the present study, $\mathrm{Sr}$ was consistently low, and was not detected in few samples, being below the limit of resolution (average $0.01-0.36 \mathrm{wt} \%)$. Fe was variable, but its presence was evident (1.08-6.96 wt\%), while Mn was low, and in a few samples it was beyond the limit of resolution (0.1$0.13 \mathrm{wt} \%$ ). Na was also low (average $0.008 \mathrm{wt} \%$ ). The variability in statistical values of $\mathrm{Al}$ and $\mathrm{Si}$ shows existence of siliciclastic inputs that may be attributed to contamination of the sample.

Interpretation: The geochemical study of $\mathrm{Sr}$ and $\mathrm{Mn}$ elements in bulk limestone showed that their contents were particularly affected by the diagenetic reaction during interaction with the meteoric waters, and can be utilized to interpret diagenetic effects ${ }^{45-47}$. The value of Sr had a 
depletion tendency during the process of meteoric diagenesis when $\mathrm{K}, \mathrm{Sr}^{+2}$ and calcite were less than 1 , while $\mathrm{Mn}$ had a tendency to be enriched in the said process, when $\mathrm{K}$ was more than 1 (refs 11,47 ). The primary mineralogy can also play a key role in the concentration of $\mathrm{Sr}$ and $\mathrm{Mn}$ components. For example, aragonite has high $\mathrm{Sr}$ and low $\mathrm{Mn}$ values because the lattice of aragonite does not accept $\mathrm{Mn}$, while calcite lattice easily accepts $\mathrm{Mn}$ and readily substitutes for $\mathrm{Ca}^{48-51}$. The $\mathrm{Mn}$ and $\mathrm{Sr}$ have a primary high abundance in calcite and aragonite respectively, and despite diagenesis these differences in relative concentration are well preserved ${ }^{11}$.

The low values of both $\mathrm{Sr}$ and $\mathrm{Mn}$ across cortical lamellae, and the XRF peaks are challenging for evaluating the original chemical composition and the later process of diagenesis. Through spectral and XRF

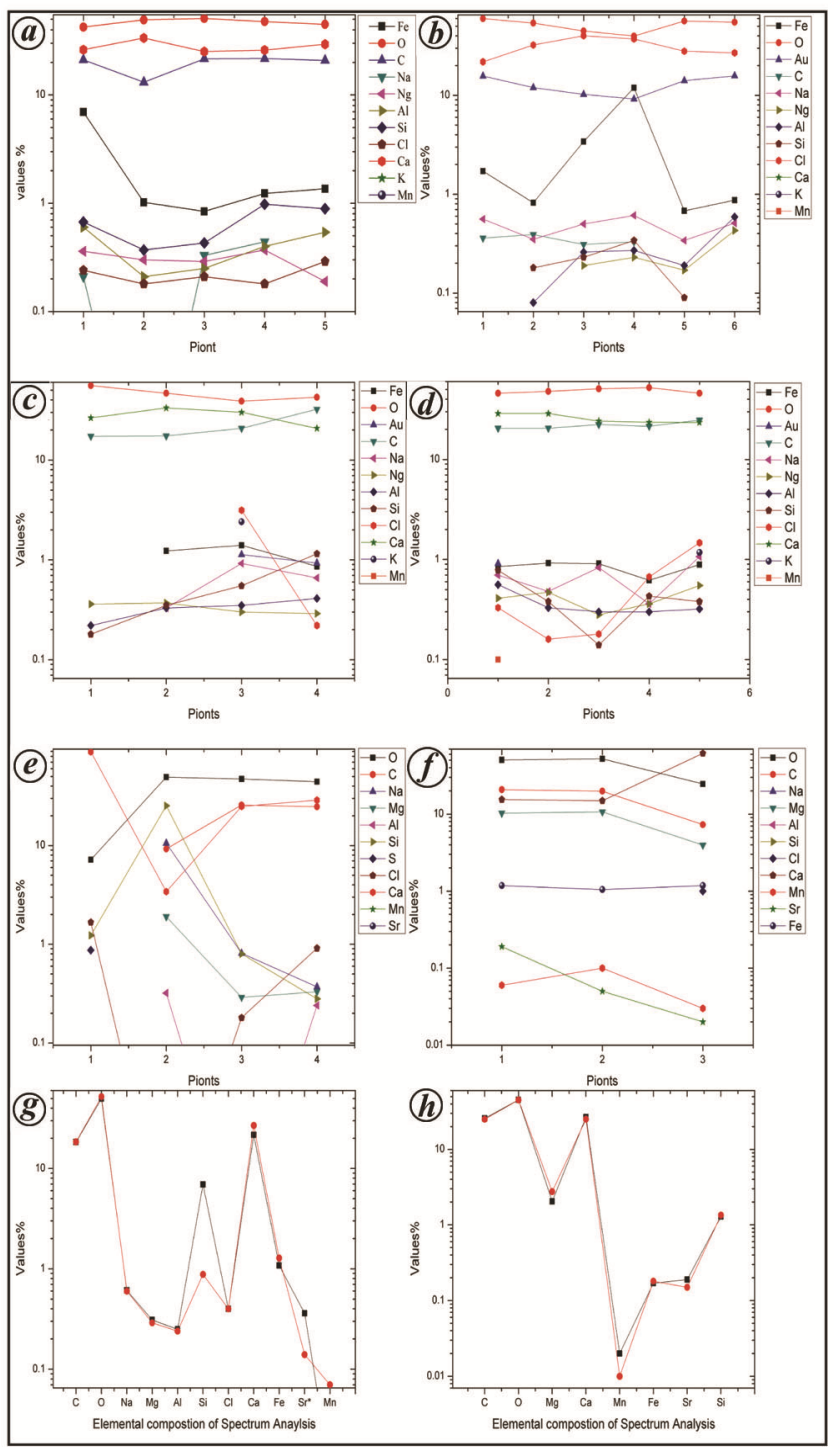

Figure 11. Graphical representation of respective EDS point $(\boldsymbol{a}-\boldsymbol{f})$ and area $(\boldsymbol{g}, \boldsymbol{h})$ analysis from Figure 10. Analytical data in statistical format are displayed in Tables 1 and 2. analyses, this study suggests that the very low Sr calculated in the individual ooids indicates that it has been detached from aragonitic components of an open marine system. Therefore, relying only on the $\mathrm{Sr}$ content for interpretation of the original mineralogy may not be a reliable indicator of the depositional fabric. However, the low values of $\mathrm{Mn}$ and micritization in the studied thin sections suggest that meteoric equilibration has occurred. The variation in $\mathrm{Sr}$ and $\mathrm{Mn}$ values in the EDS (point and area) analysis, and the XRF analyses suggests that changes in the chemical composition may have occurred due to meteoric diagenesis. Moreover, some of the ooids are bi-mineralic in nature, i.e. composition of the nucleus and surrounding lamellae is different in terms of chemical composition.

\section{Discussion}

The fabric of the current ooids is indicative of its original depositional mineralogy, whether aragonite or calcite. These ooids are inferred to have mainly original aragonitic composition, displaying fine concentric-tangential or radiated, and mosaic fabric ${ }^{9}$. According to Cantrell ${ }^{11}$, some ooids are intermediate between modern aragonite ooids and ancient calcitic ooids. The primary triggering factor involved in mineralogy changes seems to be the freshwater diagenesis.

Based on the presence of skeletal and non-skeletal allochems, the depositional environment inferred for the Jurassic ooids is high-energy shoal environment ${ }^{39,43,44}$. From petrography, it is suggested that some of the ooids were originally composed of aragonite, others preserved intermediate mineralogy, and some completely changed to calcitic composition. The well-preserved aragonitic grains possess unleached, finely delicate, concentrictangential fabric. Some aragonitic skeletal and nonskeletal grains appear leached. Finally, the ones having calcitic composition are best preserved. Besides the presence of leached and unleached non-skeletal grains, some ooids are intensively micritized in nature.

In the present study, preservation of different petrographic features (i.e. finely concentric-tangential fabric, brickwork structure, oomoldic and mosaic replacement, radial or radial concentric fabric) and geochemical data support the transformation of aragonite to calcite at some later stages (Figures 4-7). From the petrographic study, it is also suggested that the intra-cortical moldic pores are commonly filled by fine, equant crystalline calcite, which was precipitated as cement that resembles a leached relic of original calcitic or aragonitic layers in ooids. This equant cement formed on the surface of a black organic layer between lamellae, and ultimately grew towards the moldic pores formed by the dissolution of aragonite layers. The cement crystals formed on the underlying black insoluble layers and started growing toward the 
next layer, thus forming a radial fabric. The shape of the secondary precipitated cement is similar to that of the moldic pores, and the cement partially or completely occluded the intra-cortical pores that generated an overall radial fabric like the ancient ooids (Figures 4 and 5). Furthermore, the formation of ooid lamellae is owing to the presence of the black organic insoluble layer, which remains after leaching of the carbonate during freshwater diagenesis. Subsequently, the open space between two adjacent layers (i.e. intra-cortical moulds) is filled by precipitation of finely drusy equant crystalline calcite cement. The organic matter within ooid cortices is more likely assisted in fabric preservation ${ }^{11,52}$ (Figures 4-6). The intra-cortical leaching can be explained by bi-mineralic ooids, i.e. alternating aragonitic and calcitic lamellae (Figures 4 and 5). It is presumed that the aragonite leached to generate intra-cortical pores, while calcite was preserved. Examples of bi-mineral ooids are documented in the literature ${ }^{14,53,54}$.

The geochemical analysis suggests that low Mn values of the Jurassic ooids show that meteoric diagenesis had only a minor impact on the current ooids ${ }^{11}$ (Tables 1-3). In addition, the low $\mathrm{Mn}$ and low-to-high Fe values of these ooids do not provide evidence of diagenetic reactions occurring at unusually high temperatures ${ }^{47}$. Geochemical variability occurs in the trace elements such as $\mathrm{Mn}, \mathrm{Fe}, \mathrm{Sr}$ and $\mathrm{Mg}$, signifying that important variations in the original mineralogy occurred across these ooids as recorded in the Oxfordian Smackover Formation of $\mathrm{USA}^{14,55}$.

Summing up, based on a comprehensive study of ooids from the Jurassic strata in the lower to middle Indus Basin, it can be inferred that they have transformed from the original aragonite after significant diagenesis, preserving finely delicate tangential-concentric brickwork, and moldic to radiated circular fabrics (Figures 4-6). These ooids are suggested to be originally mono- and bi-mineralic in nature in their different forms.

\section{Conclusion}

(1) The early to middle Jurassic ooids from the Indus Basin, Pakistan formed in a high-energy depositional setting across the platform interior grain shoal to peritidal areas.

(2) Three different types of fabric have been reported, viz. finely laminated concentric tangential fabric, brickwork and moldic fabric, and micritized and leached fabric, showing a gradual change from aragonitic to calcitic composition.

(3) The studied ooids show common intra-cortical leaching and moldic layers, which are separated from each other by fine, organic black, insoluble layers. Such moldic pore layers indicate that these Jurassic ooids were initially composed of aragonite, which later changed to calcite. The intra-cortical moldic pores are occupied by small crystals of equant calcite cement. The equant calcite cementation and micritization in the studied ooids indicate freshwater diagenesis.

(4) The variations in $\mathrm{Sr}, \mathrm{Mn}, \mathrm{Fe}$ and $\mathrm{Mg}$ contents signify that the original mineralogy was transformed in the course of meteoric diagenesis. These ooids are therefore inferred to be originally mono- and bi-mineralic in nature.

1. Sorby, H. C., The structure and origin of limestones. Pop. Sci. Rev., 1879, 3, 134-137.

2. Bathurst, R. G. C., Carbonate Sediments and their Diagenesis, Elsevier, New York, USA, 1976.

3. Sandberg, P. A., New interpretations of great Salt Lake ooids and of ancient non-skeletal carbonate mineralogy. Sedimentology, 1975, 22, 497-537.

4. Wilkinson, B. H. and Landing, E., 'Eggshell diagenesis' and primary radial fabric in calcite ooids. J. Sediment. Res., 1978, 48, 1129 1138.

5. Mackenzie, F. T. and Pigott, J., Tectonic controls of Phanerozoic sedimentary rock cycling. J. Geol. Soc., 1981, 138, 183-196.

6. Opdyke, B. N. and Wilkinson, B. H., Paleolatitude distribution of Phanerozoic marine ooids and cements. Palaeogeog., Palaeoclimatol., Palaeoecol., 1990, 78, 135-148.

7. Mackenzie, F. T. and Morse, J. W., Sedimentary carbonates through Phanerozoic time. Geochim. Cosmochim. Acta, 1992, 56, 3281-3295.

8. Sumner, D. Y. and Grotzinger, J. P., Numerical modeling of ooid size and the problem of Neoproterozoic giant ooids. J. Sediment. Res., 1993, 63, 974-982.

9. Algeo, T. J. and Watson, B. A., Calcite, aragonite and bimineralic ooids in Missourian (upper Pennsylvanian) strata of Kansas: stratigraphic and geographic patterns of variation. In Carbonate Facies and Sequence Stratigraphy: Practical Applications of Carbonate Models (A Symposium), Soc. Econ. Paleont. Miner. Publ., Permian Basin Section, 1995, pp. 95-36.

10. Hardie, L. A., Secular variation in seawater chemistry: an explanation for the coupled secular variation in the mineralogies of marine limestones and potash evaporites over the past $600 \mathrm{my}$. Geology, 1996, 24, 279-283.

11. Cantrell, D. L., Cortical fabrics of upper jurassic ooids, Arab Formation, Saudi Arabia: implications for original carbonate mineralogy. Sediment. Geol., 2006, 186, 157-170.

12. Wilkinson, B. H., Owen, R. M. and Carroll, A. R., Submarine hydrothermal weathering, global eustasy, and carbonate polymorphism in Phanerozoic marine oolites. J. Sediment. Res., 1985, 55, 171-183.

13. Kidder, D. L. and Hall, S., Petrology and diagenetic evolution of Neoproterozoic ooids (Libby Formation, Western Montana, USA). Precambrian Res., 1993, 63, 83-96.

14. Heydari, E. and Moore, C. H., Paleoceanographic and paleoclimatic controls on ooid mineralogy of the Smackover Formation, Mississippi Salt Basin; implications for late Jurassic seawater composition. J. Sediment. Res., 1994, 64, 101-114.

15. Sandberg, P. A., An oscillating trend in Phanerozoic non-skeletal carbonate mineralogy. Nature, 1983, 305, 19.

16. Dolan, P., Pakistan: a history of petroleum exploration and future potential. Geol. Soc. London, Spec. Publ., 1990, 50, 503524.

17. Kingston, J., Undiscovered petroleum resources of south Asia. US Geological Survey Open-File Report (86-80), 1986.

18. Shah, M. I., Stratigraphy of Pakistan. GSP Mem., 2009, 22.

19. Kadri, I., Petroleum Geology of Pakistan, Pakistan Petroleum Limited Karachi, Pakistan, 1995. 


\section{RESEARCH ARTICLES}

20. Bender, F., Raza, H. A. and Bannert, D. N., Geology of Pakistan, Gebrüder Borntraeger, Berlin, Germany, 1995.

21. Robison, C., Smith, M. and Royle, R., Organic facies in Cretaceous and Jurassic hydrocarbon source rocks, southern Indus Basin, Pakistan. Int. J. Coal Geol., 1999, 39, 205-225.

22. Danilchik, W., The iron formation of the Surghar and western Salt Ranges, Mianwali district, west Pakistan. US Geol. Surv. Prof. Pap., 1961, 424, 228-231.

23. Gardezi, A. and Ghazanfar, M., A change of facies at the base of the Jurassic in district Hazara, west Pakistan. Geol. Bull. Panjab Univ., 1965, 5, 53-54.

24. Danilchik, W. and Shah, S., Stratigraphic nomenclature of formations in Trans Indus mountains Mianwali district, west Pakistan. US Geology Survey, Project Report, 1967, pp. 1-45.

25. Fatmi, A. N., Lithostratigraphic units of the Kohat-Potwar Province, Upper Indus Basin, Pakistan. Pakistan Geological Survey Memorial, 1974, vol. 10.

26. Ashraf, M., Ahmad, M. and Faruqi, F. A., Jurassic bauxite and kaolinite deposits of Chhoi area, Kala Chitta Range, Punjab, Pakistan. Geol. Bull. Punjab Univ., 1976, 41, 41-54.

27. Akhtar, M., Stratigraphy of Surghar Range. Geol. Bull. Punjab Univ., 1983, 18, 32-45.

28. Mensink, H., Mertman, D. and Ahmad, S., Facies development during the Jurassic of the Trans Indus Ranges, Pakistan. Neues Jahrb Geol. P-A, 1988, 3, 153-166.

29. Fatmi, A., Hyderi, I. and Anwar, M., Occurrence of the lower Jurassic ammonoid genus Bouleiceras from the Surghar Range with a revised nomenclature of the Mesozoic rocks of the Salt Range and Trans Indus Ranges (Upper Indus Basin). Geol. Bull. Punjab Univ., 1990, 25, 38-46.

30. Mujtaba, M. and Memon, A. M., Diagenesis and pore space development of Datta Sandstone in Salt Range and Surghar Range, Pakistan. J. Hydrol. Res., 1990, 2, 57-66.

31. Chaudhary, M., Chauhan, F. and Ghazanfar, M., Microfacies, diagenesis, environments of deposition and burial history of the Datta Formation from Bagnoter, district Abbottabad. Kashmir J. Geol., 1994, 11, 43-58.

32. Mertmann, D. and Ahmad, S., Shinawari and Samana Suk Formations of the Surghar and Salt Ranges, Pakistan: facies and depositional environments. Z. Dtsch. Geol. Ges., 1994, 145(2), 305-317.

33. Quadri, V. N. and Quadri, S. M. G. J., Anatomy of success in oil and gas exploration in Pakistan, 1915-94. Oil Gas J., 1996, 94.

34. Ahmed, S., Mertmann, D. and Manutsoglu, E., Jurassic shelf sedimentation and sequence stratigraphy of the Surghar Range, Pakistan. J. Nepal Geol. Soc., 1997, 15, 15-22.

35. Abbasi, I. A., Haneef, M., Obaid, S., Daud, F. and Qureshi, A. W., Mesozoic deltaic system along the western margin of the Indian Plate: lithofacies and depositional setting of Datta Formation, North Pakistan. Arab. J. Geosci., 2012, 5, 471-480.

36. Ahmad, S., Ahmad, S. S., Waheed, K. and Ali, A., Facies analysis and dynamic depositional modeling: implications for hydrocarbon prospecting in the Jurassic Datta Formation, Salt Ranges, Northwest Pakistan. Pak. J. Hydrocarbon Res., 2013, 22 \& 23, $63-71$.

37. Quadri, V. N. S. M., Hydrocarbon prospects of southern Indus basin, Pakistan. AAPG Bull., 1986, 70, 730-747.

38. Folk, R. L., Petrology of Sedimentary Rocks, Hemphill Publishing Company, Austin, 1980
39. Flügel, E., Microfacies of Carbonate Rocks: Analysis, Interpretation and Application, Springer, Berlin, Germany, 2004.

40. Sellwood, B. and Beckett, D., Ooid microfabrics: the origin and distribution of high intra-ooid porosity: mid-Jurassic reservoirs, England. Sediment. Geol., 1991, 71, 189-193.

41. Scholle, P. A. and Ulmer-Scholle, D. S., A color guide to the petrography of carbonate rocks: grains, textures, porosity, diagenesis. AAPG Mem., 2003, 77.

42. Flügel, E., Microfacies Analysis of Limestomes, Springer-Verlag, Berlin, Heidelberg, 1982.

43. Wilson, P. D. J. L., The lower carboniferous waulsortian facies. In Carbonate Facies in Geologic History, Springer, 1975, pp. 148-168.

44. Handford, C. R., Cantrell, D. L. and Keith, T. H., Regional facies relationships and sequence stratigraphy of a supergiant reservoir (Arab-D member), Saudi Arabia. In 22nd Annual Bob F. Perkins Gulf Coast Section SEPM Foundation Research Conference, Houston, Texas, USA, December, 2002, pp. 539-563.

45. Pingitore Jr, N. E., Submarine precipitation of void-filling needles in Pleistocene coral. Carbonate Cements. John Hopkins Press, Baltimore, 1971, pp. 68-71.

46. Brand, U. and Veizer, J., Chemical diagenesis of a multicomponent carbonate system; 1, trace elements. J. Sediment. Res., 1980, 50, 1219-1236.

47. Cantrell, D., Swart, P. and Hagerty, R., Genesis and characterization of dolomite, Arab-D reservoir, Ghawar field, Saudi Arabia. Geoarabia, 2004, 9, 11-36.

48. Krauskopf, K. B., Introduction to Geochemistry, McGraw-Hill, New York, USA, 1967.

49. Kinsman, D. J., Interpretation of $\mathrm{Sr}\left(\right.$ super $\left.^{+2}\right)$ concentrations in carbonate minerals and rocks. J. Sediment. Res., 1969, 39, 486-508.

50. Friedman, G. M., Geology and geochemistry of reefs, carbonate sediments, and waters, Gulf of Aqaba (Elat), Red Sea. J. Sediment. Res., 1968, 38, 895-919.

51. Thompson, G., A geochemical study of some lithified carbonate sediments from the deep-sea. Geochim. Cosmochim. Acta, 1972, 36, 1237-1253.

52. Shearman, D., Twyman, J. and Karimi, M. Z., The genesis and diagenesis of oolites. Proc. Geol. Assoc., 1970, 81, 561-575.

53. Given, R. K. and Wilkinson, B. H., Kinetic control of morphology, composition, and mineralogy of abiotic sedimentary carbonates. $J$. Sediment. Res., 1985, 55, 109-119.

54. Chow, N. and James, N. P., Facies-specific, calcitic and bimineralic ooids from middle and upper Cambrian platform carbonates, western Newfoundland, Canada. J. Sediment. Res., 1987, 57, 907921.

55. Swirydczuk, K., Mineralogical control on porosity type in upper Jurassic smackover ooid grainstones, southern Arkansas and northern Louisiana. J. Sediment. Res., 1988, 58, 339-347.

ACKNOWLEDGEMENTS. We thank the National Centre of Excellence in Geology, University of Peshawar, and China University of Petroleum, East China for providing the necessary laboratory facilities. We also thank the China Scholarship Council, China National Key Scientific Project (Grant No. 2016ZX05006-007) and National Centre of Excellence in Geology, University of Peshawar (Project No. PSF/ Res/KPK/PU/Earth (96)) for financial support.

Received 11 January 2019; revised accepted 4 June 2019

doi: $10.18520 / \mathrm{cs} / \mathrm{v} 119 / \mathrm{i} 5 / 831-840$ 